\title{
Assessment of Woody Species Composition and Tree Species with Highest Carbon Stock Potential in Kubayo Forest, Bale Zone, Southeastern Ethiopia
}

\author{
Demisie Asfaw Tola ${ }^{*} \quad$ Lemma Tiki Yadeta ${ }^{2} \quad$ Dejene Worku Deffere ${ }^{3}$ \\ 1.Robe Preparatory School, Bale-Robe, Ethiopia \\ 2.Ambo University, Department of Natural Resource Management, Ambo, Ethiopia \\ 3.Madda Walabu University, Collage of Natural and Computational Science, Department of Environmental \\ Science, P.O. Box 247 Bale- Robe, Ethiopia
}

\begin{abstract}
Back Ground: Climate change, mainly caused by global warming, is the most pressing environmental problem of the world today and it is a phenomenon partly resulting from abundance of carbon dioxide in the atmosphere. The problem of increasing atmospheric carbon dioxide can be addressed in a number of ways. One of such actions is forestry development and forest management undertakings that can contribute to climate change mitigation.Objective: Assessment of Woody Species Composition and Tree Species With highest Carbon Stock Potential in Kubayo Forest of Bale Zone was carried out in 2018. This study was conducted in Kubayo Forest, with the objectives of identifying the composition of woody plant species and identifying tree species with highest carbon stock potential in the area. Methodology: Data were collected from the field by measuring plants with a $\mathrm{DBH}$ of $\geq 5 \mathrm{~cm}$ and the carbon stocks of each plant was analyzed. Aboveground biomass was estimated by using allometric models. A systematic sampling method was used to conduct the woody species sampling. In order to collect woody species data, a total of 63 quadrats, each with the size of $20 \mathrm{~m}$ x $20 \mathrm{~m}$ at an interval of $100 \mathrm{~m}$ were laid along the established transects at $200 \mathrm{~m}$ apart. The result was analyzed by SPSS software, version 20. Result: The findings of the study revealed that, Juniperus procera was the most dominant and Ficus sycomorus was the least dominant one. Juniperus procera store the highest average carbon 39.76 ton/ha and the lowest carbon was recorded from Dodonaea viscosa 0.30 ton/ha among 24 tree species studied. The maximum and minimum above ground carbon stock potential of Kubayo forest was 172.53 and 81.03 ton/ha respectively. The mean above ground carbon stock of the study area was 141.06 ton/ha. The maximum and minimum AG carbon dioxide $\left(\mathrm{CO}_{2}\right)$ sequestration of the study site was 633.18 and 297.40 ton/ha respectively. The mean above ground carbon dioxide sequestration of the study area was 517.68 ton/ha. Recommendation: As a recommendation, regional and federal administrations should have to give attention on rising awareness to the local people regarding participatory forest management and sustainable use of natural resources.
\end{abstract}

Keywords: Aboveground carbon stock, Woody species, Kubayo forest,

DOI: $10.7176 /$ ALST/77-05

Publication date: January $31^{\text {st }} 2020$

\section{INTRODUCTION}

\subsection{Background}

Human beings have become a component in the earth's system, driving and accelerating global warming through the rapid release of greenhouse gases (GHGs) into the atmosphere. Human beings alter the composition of the atmosphere through increasing the concentration of greenhouse gases (GHGs) in the atmosphere by fossil fuel burning which represents about two-third of the global emissions and by deforestation and land use changes representing about one-third. These are anthropogenic causes of climate change. There is no doubt that our climate is changing. This will pose huge challenges to nations, organizations, enterprises, cities, communities and individuals. Developing countries will suffer most from adverse consequences of climate change, and the highly vulnerable regions and people are already being affected (Yitebitu Moges et al., 2010).

The 1997 Kyoto Protocol, the first major international agreement on climate change, recognized that forests are playing an important role in mitigating climate change by naturally taking carbon out of the atmosphere, thereby reducing the impact of CO2 emissions (IPCC, 2003; IPCC, 2007; Perschel et al., 2007). Forests play an important role in the global carbon balance. As both carbon sources and sinks, they have the potential to form an important component in efforts to combat global climate change. FRA (2010) estimated that the world's forests store $289 \mathrm{Gt}$ of carbon in their biomass alone. As sources of GHGs, deforestation accounts for approximately $20 \%$ of anthropogenic emissions (FAO, 2006; Stern, 2007).

Although deforestation is reported to represent about $20 \%$ of the global GHGs emissions, regionally the figure varies. About 70\% GHGs emissions is caused by deforestation in Africa (Gibbs et al., 2007). For the world as a whole, carbon stocks in forest biomass decreased by an estimated 0.5 Gt annually during the period 2005-2010, mainly because of a reduction in the global forest area. On the other hand, the recent IPCC report estimated that 
the global forestry sector represents over $50 \%$ of global greenhouse mitigation potential (IPCC, 2007).

When forests are transformed into agriculture, the subsequent land use systems implemented determine the amount of potential carbon restocking that takes place. Annual crop systems will on average contain only 3 tons $\mathrm{C}$ ha-1, intensive tree crop plantations 30-60 tons carbon ha-1, which is 1 and $10-25 \%$ of the forest biomass and carbon stock. The annual $\mathrm{C}$ sequestration rate (increment of standing stock) may be the same for these three of woody plant species types (annual crop, tree plantation and forest) about 3 tons $\mathrm{C}$ ha- $1 \mathrm{yr}-1$, but the mean residence time differs from 1, 10 to 83 years. Changes in carbon stocks between woody plant species and land use types relate primarily to this 'mean residence time' of the carbon in the biomass (FAO, 2006).

Vegetation's can play a significant role in regulating the global climate. They play a key role in both sinks and sources of carbon dioxide. Globally, forests act as a natural storage for carbon, contributing approximately $80 \%$ of terrestrial above-ground and $40 \%$ of terrestrial belowground biomass carbon storage (Kirschbaum, 1996). Most terrestrial biomass carbon storage is in tree trunks, branches, foliage, and roots which is often called biomass. Therefore, forest biomass is an important element in the carbon cycle, specifically in carbon sequestration. Forests used to quantify pools and fluxes of greenhouse gases (GHGs) from the terrestrial biosphere associated with land use land cover changes (Cairns et al., 2003). In addition, forests are thought to provide a more cost-effective means of reducing global CO2 emissions than other sectors (IPCC, 2007).

Ethiopian People particularly in the rural areas of the country are highly dependent on forest resources to fulfill their basic needs such as fuel wood for cooking, heating, foliage for livestock, and timber for shelter and non-timber products for medicine. Environmental degradation and deforestation have been taking place for many years in the country. Especially during the last century, Ethiopia's forest and woodlands have been declining both in size (due to deforestation) and quality (due to degradation) (EFAP, 1994).

Climate change impacts will affect everyone, particularly our country as we are situated in the sub-Saharan Africa, where countries are already vulnerable to climate variability and have the least capacity to respond (IPCC, 2007). Ethiopia can benefit from global initiatives from clean energy development and reduced deforestation. Ethiopia is experiencing the effects of climate change such as an increase in average temperature and change in rainfall patterns.

Unlike in the developed countries, Ethiopia does not have well organized and efficient carbon inventories and databank to monitor and enhance carbon sequestration potential of different forests. Studies have not been conducted on Kubayo forest to evaluate woody species composition and tree species with high carbon stock potential in the study area. Therefore, the main objective of this study was to evaluate and document the woody species composition and to identify species with high carbon stock potential in Kubayo Forest.

\section{MATERIALS AND METHODS}

\subsection{Description of the Study Area}

The current study was conducted in, Gololcha district, Kura Wada kebele, which is found in Bale Zone of Oromia regional state. Kubayo forest located at about $15 \mathrm{~km}$ from Jara Town on Dire Shek Husien Road. It is $117 \mathrm{~km}$ from Robe town and $547 \mathrm{~km}$ from Addis Ababa towards east direction. Kubayo Forest is one of the dry afromontane forests in South East parts of Ethiopia and has an altitudinal gradient of ranging from 1923 to $2225 \mathrm{~m}$ above sea level with the geographical location of $7029^{\prime} 23^{\text {ee }} \mathrm{N}$ to $7034^{\prime} 52^{\text {ee }} \mathrm{N}$ and $40039^{\prime} 56^{\text {ce }} \mathrm{E}$ to $40045^{\prime} 55^{\text {ee }} \mathrm{E}$. According to the Gololcha District Agriculture and Rural Development Office (GDARDO), the forest covers a total area of 153 ha and it is a home for a variety of flora and fauna. 


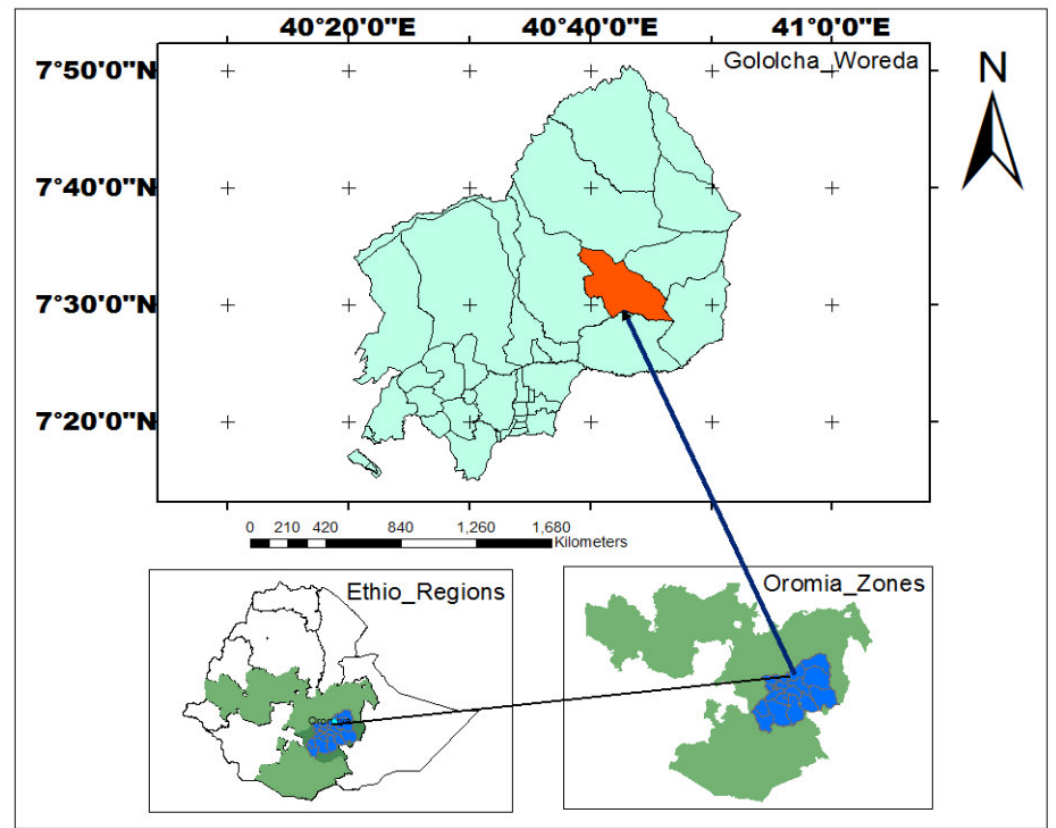

Figure 1: Map of Kubayo Forest in Gololcha District (Source: Ethio GIS)

The mean annual temperature of the district is $19^{\circ} \mathrm{c}$. The lowest temperature is $15^{\circ} \mathrm{c}$ and highest is $23^{\circ} \mathrm{c}$ respectively. The mean annual rainfall is $750 \mathrm{~mm}$ whereas the lowest and highest rainfall is $580 \mathrm{~mm}$ and $920 \mathrm{~mm}$ respectively.

The vegetation available in Kubayo Forest is dominated by natural vegetation species such as Juniperus procera (Hindheessa), Combretum molle (bika), Acokanthera schimperi(keraru), Olea europaea (Ejersa), Cordia africana (wadesa), Maytenus arbutifolia (kombolcha), Croton macrostachyus (bakkanniisa), Podocarpus falcatus (birbirsa) and Acacia abyssinica (Laaftoo), diverse species of bushes, shrubs and herbs.

\subsection{Methodology}

\subsubsection{Delineation of the study site}

Delineation of the forest boundaries were the first step in evaluating woody species composition and identifying species with high carbon stock potential in Kubayo Forest. The boundary of the study forest area was delineating by taking geographic coordinates with global positioning system (GPS) at each turning point. The GPS points that were taken from the study site to indicate each sample plots were recorded.

\subsubsection{Stratification of the study area}

Stratification helps in the forest in order to take accurate data from the field, to save time and energy as well as to maintain the homogeneity of the area. Different options can be used for stratifying the study area including land use, plant species, slope, drainage, age of plants, altitude, proximity to settlement, aspect and position of hill slopes, as stated by Bhishma et al. (2010). For this study, the altitude difference was used. Therefore, the study site were stratified in three categories of altitude i.e., lower, middle and upper (starting from the lowest to the top of the mountain).

\subsubsection{Sampling design}

There are varieties of sample quadrat designs that are applicable in forest inventory for the purposes of timber volume, biomass or carbon assessments. The 'nested quadrat designs' which is appropriate for inventories in natural forests where there is high variability in tree size, distribution and structure (Brown, 1997) were used. Even though, both rectangular and circular nested quadrats are applied in most of the forest carbon measurements, rectangular quadrat is more advantageous and recommended for the study area. This is because rectangular quadrats tend to include more of within-quadrat heterogeneity, and thus be more representative than the circular quadrats of the same area (Brown, 1997; Hairiah et al., 2001).

In this study area, there is high variability in topography and woody plant species types. Hence, a rectangular nested quadrat design which is appropriate to incorporate the variable tree sizes; was used. A transect is set up deliberately across areas where there are rapid changes in vegetation and marked environmental gradients (Kent and Coker, 1992).

Accordingly, nine transect lines were laid for the selected forest each at an interval from the lower, middle and upper altitude of the mountain. Accordingly seven quadrats from each transects with a total of 63 quadrats of $20 \mathrm{~m}$ x $20 \mathrm{~m}$ (400 m2 each) in size was systematically established for woody plant species records and carbon stock estimation (Brown, 1997). A transect is a line along which samples of woody plant species are taken. It is 
set up purposively across areas where there are rapid changes in woody plant species and marked environmental gradients (Kent and Coker, 1992). Quadrats were laid systematically at every $100 \mathrm{~m}$ along transect lines, which is $200 \mathrm{~m}$ apart from each other. In order to eliminate any influence of the road effects on the forest biomass, all the quadrats were lay at least $100 \mathrm{~m}$ away from the edge of the forest.

\subsubsection{Woody plant species identification}

The estimations of above and belowground carbon depend on the aboveground biomass of living woody plant species. To estimate the above ground biomass, all woody plant species within selected sites having DBH $\geq 5 \mathrm{~cm}$ should be identified and recorded. Plant identification was doing at the field using their local name and useful trees and shrubs for Ethiopia (Azene Bekele, 1993 \& 2007). Each woody plant which is listed at field again cross checked its botanic name using Flora of Ethiopia and Eritrea.

\subsubsection{Estimation of above ground carbon stock (AGC)}

The above ground biomass consists of all living vegetation above the soil, inclusive of stems, stumps, branches, bark, seeds and foliage. The DBH of individual trees with DBH greater than or equal to $5 \mathrm{~cm}$ was measured in each sampling plots. From the different available allometric equations to estimate the above ground biomass, the model that was developed by Brown et al., (1989) is selected for the study site since the general criteria described by the author are similar to the study area. The general equation that was used to calculate the above ground biomass is given below:

$\mathrm{AGB}=34.4703-8.0671(\mathrm{DBH})+0.6589(\mathrm{DBH} 2)$

Where, AGB is above ground biomass, $\mathrm{DBH}$ is diameter at breast height.

Estimation of above ground carbon content

$$
\mathrm{AGC}=\mathrm{AGB} \times 0.5
$$

Where, $\mathrm{AGC}=$ above ground carbon content

To estimate the amount of $\mathrm{CO} 2$ sequestered in the above ground biomass, the above ground carbon has to be, multiplied by 3.67 . Because the ratio of $\mathrm{CO} 2$ to $\mathrm{C}$ is $(44 / 12)=3.67$

\subsection{Statistical Analysis}

The data gathered from the field was fed into a computer and organized on the excel data sheet for the subsequent analysis of the data. After recording and organizing the data; the quantitative structure analysis were made using Microsoft excel of 2010 and Statistical Package for Social Science (SPSS) software version 20. Based on the collected data (DBH), biomasses of each tree species in all sample quadrats were calculated by using developed allometric model and converted in to quadrat and hectare base by using conversion factor. The relationship between different parameter was tested by One Way ANOVA.

\section{RESULTS AND DISCUSSION}

\subsection{Results}

\subsubsection{Woody species composition of Kubayo forest}

Kubayo Forest is categorized as dry Afromontane forest type vegetation. The forests had different species composition, DBH, height and density like that of other dry Afromontane forests. The most characteristic plant species in dry Afromontane such as Juniperus procera, Olea europaea, Croton macrostachyus, Podocarpus falcatus, Acacia albida and Acokanthera schimperi were found in Kubayo forests. The forest altitude ranges from (1923 - $2225 \mathrm{~m})$ a.s.1.

A total of 24 woody plants species, were recorded with the $\mathrm{DBH} \geq 5 \mathrm{~cm}$ within 63 quadrats in Kubayo forest at eastern part of Bale, Ethiopia. Among such species, Juniperus procera was the dominant species counting $\mathbf{1 7 . 0 6 \%}$ (239) trees, and Acokanthera schimperi and Combretum molle were the second and third dominant species recorded with $\mathbf{7 . 5 7 \%}$ (106) and 5.85\% (82) trees respectively. Acacia albida 5.42\% (76) trees, Dombeya torrida and Myrsine africana L. covered with equal amount of trees $5.21 \%$ (73). Ficus sycomorus were the least dominant species which covers $0.57 \%$ ( 8 trees) in the study forest. Grewia bicolour, Olea capensis and Rhus vulgaris were the next least dominant species covering $0.86 \%$ (12 trees), 1\% (14 trees) and $1.28 \%$ (18 trees) respectively.

Accordingly, the frequency distribution of the species showed that Juniperus procera Hochst. Ex Endl. and Acokanthera schimperi were the most frequent tree species occurred in the study area (in all plots). Myrsine africana L., Combretum molle and Acacia albida were also occurred in 58, 57 and 53 plots out of 63 plots respectively. The species with the least occurrence in the study site were Ficus sycomorus only in 6 plots, Grewia bicolour in 9 plots and Olea capensis in 14 plots (Table 1).

$$
\begin{aligned}
& \text { Frequency } \%=\quad \text { Total number of quadrate studied } \\
& \text { Relative density }=\frac{\text { Number of individuals of the species }}{\text { Total number of individuals of all the species }} \times 100
\end{aligned}
$$


Table 1: Tree code, Vernacular name, Scientific name, Number of trees, number of plots, Mean DBH and height, $\%$ Frequency of the species and Relative density

\begin{tabular}{|c|c|c|c|c|c|c|c|c|}
\hline 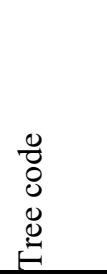 & 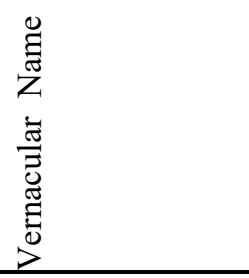 & 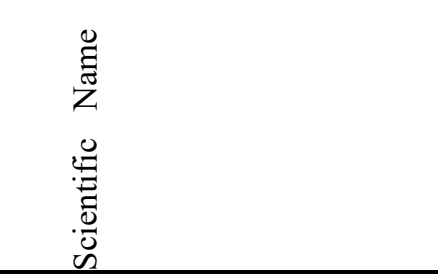 & 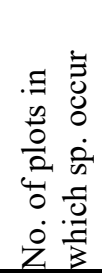 & 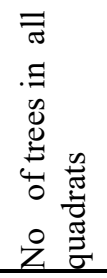 & 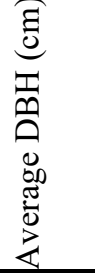 & 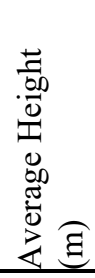 & 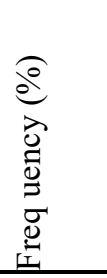 & 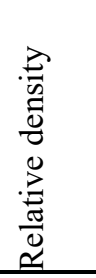 \\
\hline$D A_{1}$ & Bekenis & Croton macrostachyus & 22 & 43 & 20.26 & 7.07 & 34.92 & 3.07 \\
\hline DA2 & Bika & Combretum molle & 57 & 82 & 16.84 & 6.29 & 90.48 & 5.85 \\
\hline DA3 & Birbirsa & $\begin{array}{l}\text { Podocarpus falcatus (P. } \\
\text { gracilior) }\end{array}$ & 27 & 48 & 29.35 & 13.21 & 42.86 & 3.43 \\
\hline $\mathrm{DA}_{4}$ & Danisa & $\begin{array}{l}\text { Dombeya torrida subsp. } \\
\text { torrida (D. goetzenii) }\end{array}$ & 29 & 73 & 11.21 & 3.92 & 46.03 & 5.21 \\
\hline DA5 & Debobes & Rhus vulgaris & 17 & 18 & 16.83 & 6.94 & 26.98 & 1.28 \\
\hline DA6 & Dokonu & Grewia ferruginea & 15 & 20 & 13.45 & 5.05 & 23.81 & 1.43 \\
\hline DA7 & Ejersa & $\begin{array}{l}\text { Olea europaea subsp. } \\
\text { cuspidata (Olea africana) }\end{array}$ & 23 & 52 & 20.88 & 9.04 & 36.51 & 3.71 \\
\hline DA8 & Galle & $\begin{array}{l}\text { Psydrax schimperiana subsp. } \\
\text { schimperiana }\end{array}$ & 29 & 32 & 16.91 & 5.66 & 46.03 & 2.28 \\
\hline DA9 & Gegema & Olea capensis & 14 & 14 & 18.36 & 7.57 & 22.22 & 1.00 \\
\hline DA10 & Gerbi & $\begin{array}{l}\text { Acacia albida (Faidherbia } \\
\text { albida) }\end{array}$ & 53 & 76 & 10.41 & 3.63 & 84.13 & 5.42 \\
\hline DA11 & Hallo & Acacia bussei & 18 & 37 & 17.73 & 7.54 & 28.57 & 2.64 \\
\hline DA12 & Haroressa & Grewia bicolour & 9 & 12 & 8 & 2.58 & 14.29 & 0.86 \\
\hline DA13 & Hindheshabasha & $\begin{array}{l}\text { Juniperus procera Hochst. Ex } \\
\text { Endl. }\end{array}$ & 63 & 239 & 55.10 & 16.23 & 100.00 & 17.06 \\
\hline DA14 & Ittecha & $\begin{array}{l}\text { Dodonaea viscosa (D. } \\
\text { angustifolia) }\end{array}$ & 29 & 64 & 7.95 & 3.42 & 46.03 & 4.57 \\
\hline DA15 & kombolcha & Maytenus arbutifolia & 41 & 68 & 10.13 & 3.49 & 65.08 & 4.85 \\
\hline DA16 & Lafto & Acacia sieberiana & 41 & 65 & 10.14 & 3.71 & 65.08 & 4.64 \\
\hline DA17 & mi'essa & Euclea racemosa subsp. & 41 & 63 & 14.56 & 6.33 & 65.08 & 4.50 \\
\hline DA18 & Kechema & Myrsine africana L. & 58 & 73 & 9.66 & 3.45 & 92.06 & 5.21 \\
\hline DA19 & Keraru & Acokanthera schimperi & 63 & 106 & 16.83 & 6.84 & 100.00 & 7.57 \\
\hline DA20 & Kiltu & Ficus sycomorus & 6 & 8 & 48.38 & 9.63 & 9.52 & 0.57 \\
\hline DA21 & Wachu & Acacia seyal & 28 & 45 & 19.96 & 7.44 & 44.44 & 3.21 \\
\hline DA22 & Woddessa & Cordia africana & 32 & 69 & 12.87 & 4.2 & 50.79 & 4.93 \\
\hline DA23 & Tatessa & Rhus glutinosa & 24 & 59 & 11.03 & 4.83 & 38.10 & 4.21 \\
\hline DA24 & $\begin{array}{l}\text { Tedecha } \\
\text { Sum } \\
\text { Average }\end{array}$ & Acacia tortilis & 25 & $\begin{array}{l}35 \\
1401\end{array}$ & $\begin{array}{l}16.29 \\
17.21 \\
17.21\end{array}$ & $\begin{array}{l}5.34 \\
6.78 \\
6.78 \\
\end{array}$ & 39.68 & 2.50 \\
\hline
\end{tabular}

\subsubsection{DBH and height distribution of Kubayo forest}

The DBH class distribution of the trees classified in to five, $5-15 \mathrm{~cm}, 16-25 \mathrm{~cm}, 26-35 \mathrm{~cm}, 36-45 \mathrm{~cm}$ and $>45 \mathrm{~cm}$. As shown from the graph more DBH class was found in $5-15 \mathrm{~cm}$. The second highest number was recorded from $16-25 \mathrm{~cm}$ while the least distribution was $36-45 \mathrm{~cm}$. The distribution indicated that there was a decrease in the number of individuals towards the higher DBH class distribution except the highest DBH class. This shows that the number of tree decreased with an increased in DBH class and the smallest DBH class size indicated more density of species than the rest of the classes in the DBH distribution. In general, DBH of trees in class $5-15 \mathrm{~cm}$ was found to be dominant followed by $16-25 \mathrm{~cm}, 26-35 \mathrm{~cm},>45 \mathrm{~cm}$ and $36-45 \mathrm{~cm}$, respectively (Figure 2).

As mentioned in the table 1, the mean maximum DBH value in the studied area was recorded for Juniperus procera with the average DBH value of $55.10 \mathrm{~cm}$ followed by Ficus sycomorus and Podocarpus falcatus with the average DBH value of $48.38 \mathrm{~cm}$ and $29.35 \mathrm{~cm}$ respectively. The least mean DBH were recorded for Dodonaea viscosa with mean value of $7.95 \mathrm{~cm}$ followed by Grewia bicolour and Myrsine africana L with the value of $8 \mathrm{~cm}$ and $9.66 \mathrm{~cm}$ respectively (Table 1 ). 


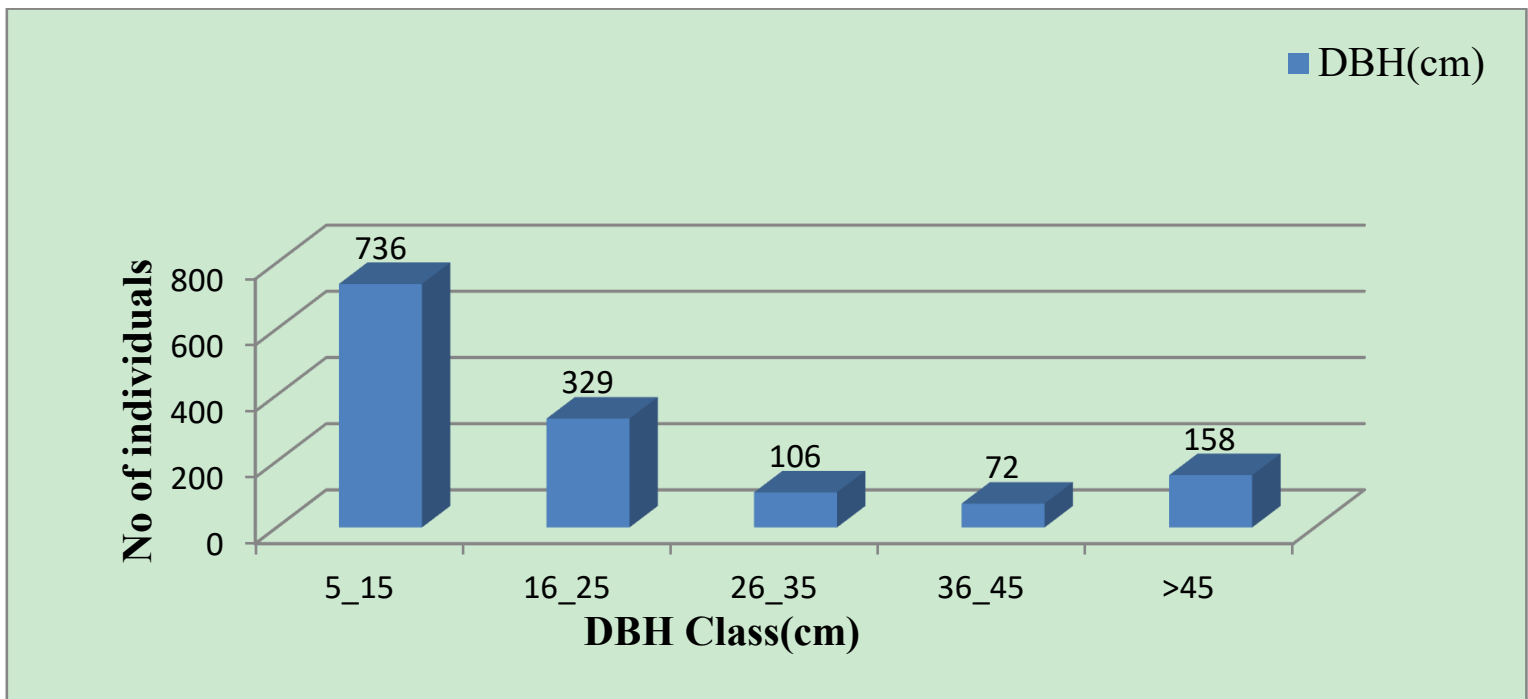

Figure 2: DBH size class distributions of trees in the study site

Height class distribution of this study site were classified in to $\leq 5,6-10,11-15,16-20$ and $>20$. As shown in Figure 3 below, more number of individuals has been found in (6-10) or 32.55\% out of the total listed ones. The second more number of individuals were found in (11-15) or account for $32.19 \%$. The least number of individuals were recorded in $>20 \mathrm{~m}$ and account for $6.6 \%$.

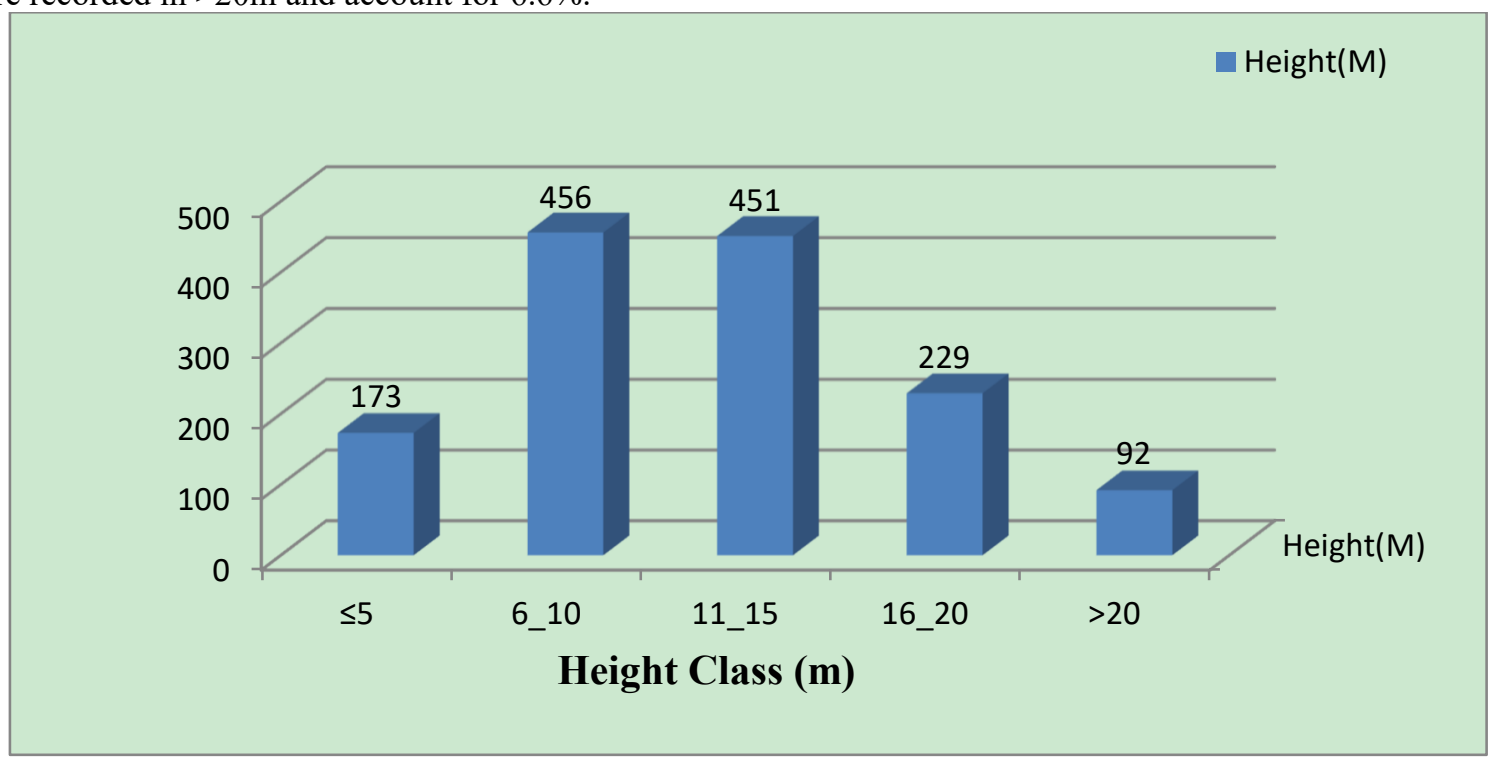

Figure 3: Height class distribution of all trees recorded in the study site

\subsubsection{Carbon stock in AG carbon pools of different tree species}

The amount of Carbon varied between different tree species. According to the current biomass inventory of the Kubayo Forest, Juniperus procera and Ficus sycomorus were the reserves of enormous density of carbon with average AGC 39.76 and 29.66 ton/ha of average carbon density. The results showed that Juniperus procera has the highest average above ground biomass, with average carbon of 39.76 ton/ha, respectively. The lowest carbon was recorded from Dodonaea viscosa and Grewiabicolour with equal amount of carbon 0.30 ton/ha of above ground carbon stock among 24 tree species studied. 
Table 2: Biomass carbon stock of tree species (ton/ha)

\begin{tabular}{|c|c|c|c|c|c|c|}
\hline$S / N$ & $\begin{array}{l}\text { Species } \\
\text { Scientific Name }\end{array}$ & $\begin{array}{l}\text { Aver } \\
\text { DBH }\end{array}$ & $\begin{array}{l}\text { Aver } \\
\text { Height }\end{array}$ & $\operatorname{AGB}(\mathrm{t} / \mathrm{ha})$ & $\mathrm{AGC}(\mathrm{t} / \mathrm{ha})$ & $\mathrm{AGCO}_{2}(\mathrm{t} / \mathrm{ha}$ \\
\hline 1 & Croton macrostachyus & 20.26 & 7.07 & 7.07 & 3.54 & 12.98 \\
\hline 2 & Combretum molle & 16.84 & 6.29 & 4.27 & 2.14 & 7.84 \\
\hline 3 & Podocarpus falcatus & 21.43 & 8.83 & 8.21 & 4.10 & 15.06 \\
\hline 4 & Dombeya torrida & 18.43 & 7.61 & 5.48 & 2.74 & 10.06 \\
\hline 5 & Rhus vulgaris & 29.35 & 13.21 & 18.26 & 9.13 & 33.52 \\
\hline 6 & Grewia ferruginea & 29.35 & 13.21 & 18.26 & 9.13 & 33.52 \\
\hline 7 & Olea europaea & 29.35 & 13.21 & 18.26 & 9.13 & 33.52 \\
\hline 8 & Psydrax schimperiana & 16.91 & 5.66 & 4.32 & 2.16 & 7.93 \\
\hline 9 & Olea capensis & 18.36 & 7.57 & 5.42 & 2.71 & 9.95 \\
\hline 10 & Acacia albida & 10.41 & 3.63 & 1.09 & 0.55 & 2.01 \\
\hline 11 & Acacia bussei & 17.73 & 7.54 & 4.93 & 2.46 & 9.04 \\
\hline 12 & Grewia bicolour & 8.00 & 2.58 & 0.61 & 0.30 & 1.11 \\
\hline 13 & Juniperus procera. & 55.1 & 16.23 & 79.52 & 39.76 & 145.92 \\
\hline 14 & $\begin{array}{l}\text { Dodonaea viscosa } \\
\text { (D. angustifolia) }\end{array}$ & 7.95 & 3.42 & 0.60 & 0.30 & 1.10 \\
\hline 15 & Maytenus arbutifolia & 10.13 & 3.49 & 1.02 & 0.51 & 1.87 \\
\hline 16 & Acacia sieberiana & 10.14 & 3.71 & 1.02 & 0.51 & 1.87 \\
\hline 17 & Euclea racemosa & 14.56 & 6.33 & 2.83 & 1.42 & 5.20 \\
\hline 18 & Myrsine africana & 9.66 & 3.45 & 0.90 & 0.45 & 1.65 \\
\hline 19 & Acokanthera schimperi & 16.83 & 6.84 & 4.27 & 2.13 & 7.83 \\
\hline 20 & Ficus sycomorus & 48.38 & 18.88 & 59.32 & 29.66 & 108.85 \\
\hline 21 & Acacia seyal & 19.96 & 7.44 & 6.80 & 3.40 & 12.47 \\
\hline 22 & Cordia africana & 12.87 & 4.20 & 1.99 & 0.99 & 3.65 \\
\hline 23 & Rhus glutinosa & 11.03 & 4.83 & 1.28 & 0.64 & 2.35 \\
\hline 24 & Acacia tortilis & 16.29 & 5.34 & 3.90 & 1.95 & 7.15 \\
\hline
\end{tabular}

\subsubsection{Estimation of above ground biomass (AGB)}

The biomass estimation method was used to determine the biomass and the carbon stock of the tree in the study site known as Kubayo forest. The result shows that the maximum and minimum above ground biomass (AGB) was 345.06 and 162.07 ton/ha respectively. The average AGB stock of the study site was recorded 282.11 ton/ha.

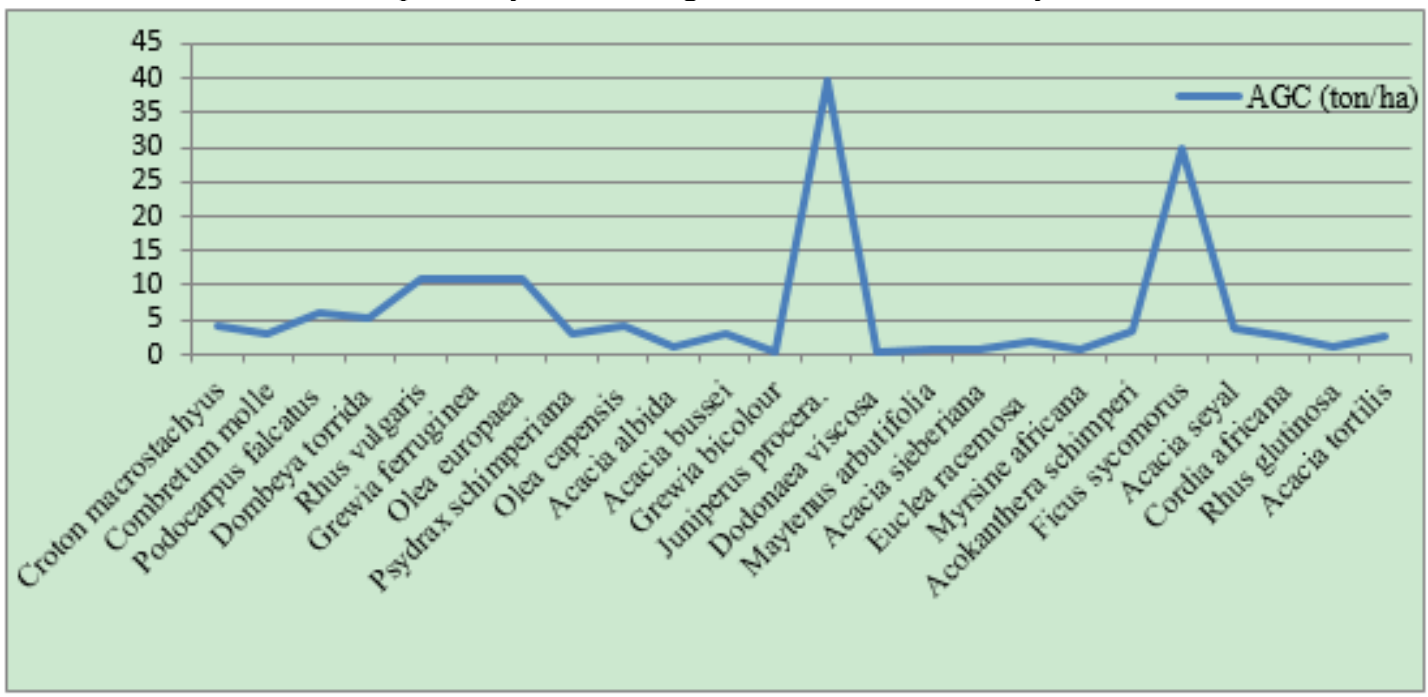

Figure 3: The average AGC stock in all species)

\subsubsection{Carbon stock in above ground biomass (AGC)}

The maximum and minimum above ground carbon stock potential of Kubayo forest was 172.53 and 81.03 ton/ha respectively. The mean above ground carbon stock of the study area was $141.06 \mathrm{ton} / \mathrm{ha}$. The maximum and minimum AG carbon dioxide (CO2) sequestration of the study site was 633.18 and 297.40 ton/ha respectively. The mean above ground carbon dioxide sequestration of the study area was 517.68 ton/ha (Appendix 2). This is graphically represented bellow. 


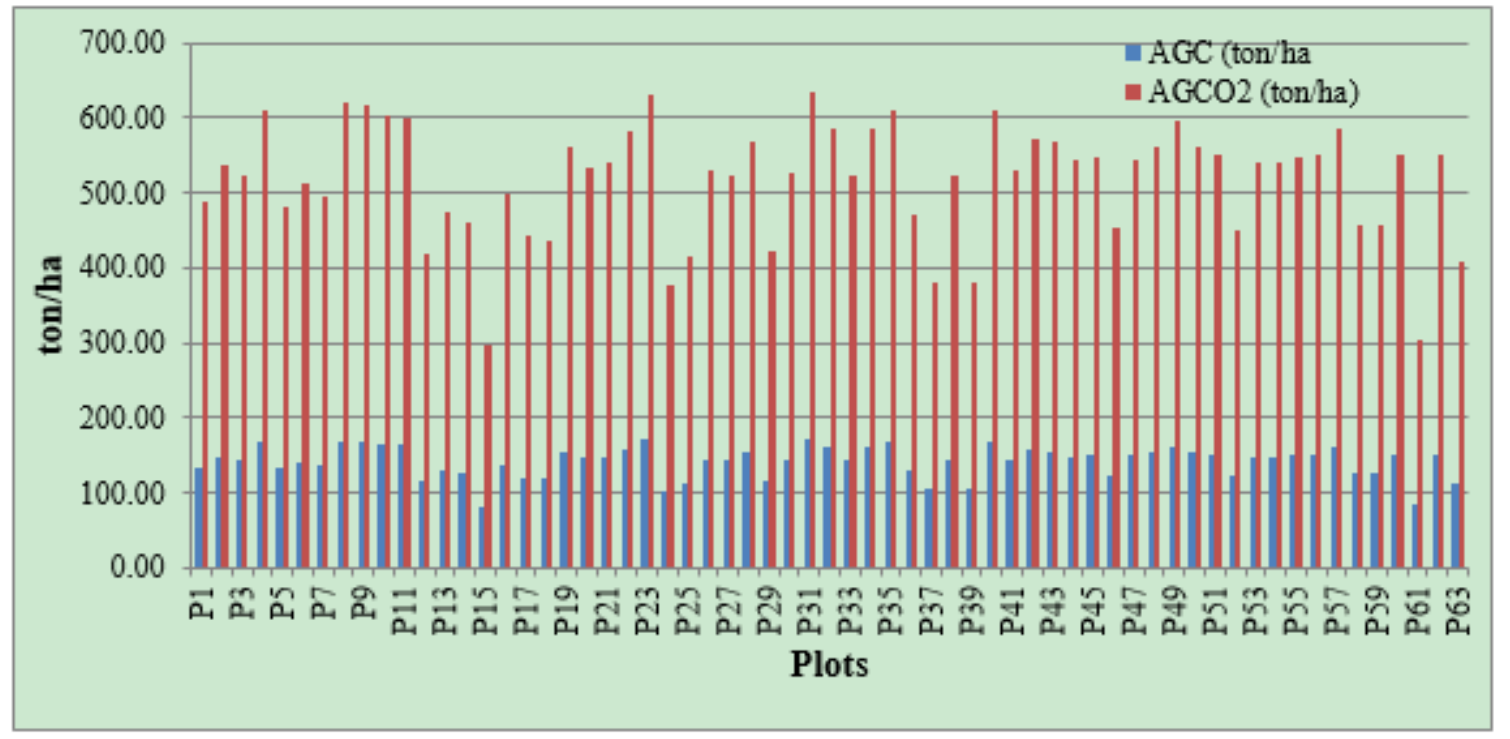

Figure 6: $\mathrm{AGC}$ and $\mathrm{AGCO}_{2}$ vs plots

\subsection{Discussion}

\subsubsection{Woody species composition}

Kubayo forest is characterized by species like Juniperus procera, Combretum molle, Acokanthera schimperi, Olea europaea, Cordia Africana, Maytenus arbutifolia, Croton macrostachyus, Podocarpus falcatus, Acacia abyssinica etc. and it had different species composition, DBH, height, density and frequency. In addition, the altitudinal range of this study forest $(1923-2225 \mathrm{~m})$ found within the altitudinal range for dry evergreen afromontane forest (1500-3400 m). Thus, due to these conditions Kubayo forest can be grouped to dry evergreen afromontane forest. Human interaction like farming and deforestation is clearly observed in the study area; which might lead for the forest disturbance. As indicated by Kidanemariam Kassahun (2014), the increasing population of Ethiopia has resulted in excessive forest clearing for agricultural use, overgrazing and exploitation of the existing forests for fuel wood, fodder and construction materials have also increased as a result the forest structure and carbon stock potential is being affected.

\subsubsection{The arrangement of DBH and height class in Kubayo forest}

The dispersal of trees was influenced by the concentration and number of individual trees distributed in the carbon pools. As the study clearly showed, the number of individual tree was high in the first (5-15) and second (16-25) DBH classes, whereas relatively small in the rest of three classes. The height distribution also showed variation among classes. High numbers of trees were found in the second (6-10) and a third (11-15) class of height distribution, and the least was recorded with the rest classes.

Distribution of DBH and height classes in the study area exhibited relatively an inverted J- shaped distribution. This arrangement suggests that high number of individuals counted for the lower DBH classes while the middle and higher DBH classes showed a decreasing density. This condition indicates that there was high regeneration potential in the study site. Analysis of plant structures in this study forest using frequency distribution of the height and diameter classes of woody species could provide an insight into their regeneration status (Brokaw 1987; Burrows 1990; Silvertown 1982; Silvertown \& Doust 1993).

\subsubsection{Biomass potential of Kubayo forest}

Forest has a large potential for temporary and long term carbon storage (Houghton, 2001). In the forest ecosystems, greater carbon is stored in a large, long-lived species and in species with dense wood. Similarly, the current study of the site indicates unbalanced tendency of carbon stock input in the above ground. Species such as Juniperus procera, Acokanthera schimperi and Combretum molle contributed for the large amounts of biomass and carbon stocks while Dodonaea viscosa, Grewiabicolour and Myrsine africana had less contribution. This unequal contribution of species to carbon stock of the forest site could probably be due to the density, age and size difference among species.

The presence of species characterized by large individuals occurring on middle altitude could have an effect on AGB and carbon stock, because few large individuals can account for large proportion of the plots above and below ground carbon according to Brown and Lugo (1992). The maximum and minimum above ground carbon pool was 172.53 and 81.03 ton/ha respectively. The average carbon stock recorded in above ground was also 141.06 ton/ha.

Comparing with other recent studies the biomass and carbon stock of the study site (Kubayo forest) was 
almost proportional with a little bit variation to Yerer Forest (Aregu Balleh, 2015) and Meskel Gedam Forest (Dagnachew Tefera, 2016) an average AGC storage of 140.60 and 146.34 ton/ha respectively. As indicated by Murphy and Lugo (1986), the global AGC in tropical dry and wet forests ranged between 30-275 ton/ha and 2131173 ton/ha respectively and due to this, the result of the study site had almost a positive carbon stock potential and this indicates the forest status was well managed and protected even if some human interference were there.

Despite of the fact that in most of the studies larger amount of carbon were found on the northern aspect; however, for this particular study the higher amount of carbon stock for AGC and BGC were recorded on Western aspect. The lowest AGC and BGC were found on the Southern aspect.

\section{CONCLUSION AND RECOMMENDATIONS}

This study was conducted at Kubayo forest which makes a significant contribution to carbon sequestration and therefore can generate carbon credits in Ethiopia. It is also expected that much income can be earned by selling carbon credits in the carbon market. A total of 24 different woody species were recorded of which Juniperus procera counting $17.06 \%$ (239) trees and Acokanthera schimperi 7.57\% (106) and dominant species. Ficus sycomorus covers $0.57 \%$ (8 trees) and Grewia bicolour covering $\mathbf{0 . 8 6 \%}$ (12 trees) were the least dominant species in the study forest. The density of tree species decreases as the DBH and height classes increases in the forest. This implies that, the predominance of small sized tree species in the lower classes than in the upper classes.

Analysis of carbon stocks in different tree species of the forest responded differently where the highest carbon stock was recorded for Juniperus procera Hochst. Ex Endl.was dominant tree species, followed by Ficus sycomorus. The average carbon stock recorded in above ground was 141.06 ton/ha. Where, the maximum and minimum above ground carbon pool was 172.53 and 81.03 ton/ha respectively.

The average AG carbon stock in the forest area was big and the result is comparable to other study results of forests in Ethiopia. This indicates the contribution of the forest for carbon sequestration and hence mitigation of climate change is very significant.

Finally, as a recommendations, the regional and federal administrations should have to give attention on rising awareness to the local people regarding participatory forest management and sustainable use of natural resources. To get monetary benefit of carbon dioxide mitigation in conservation and further enhancement of the forests, the carbon sequestration of the study forest should be integrated with projects such as REDD+.

\section{Conflicts of Interest}

The authors did not declare any conflict of interest.

\section{Acknowledgement}

This study was carried out with the financial assistance Farm Africa, REDD+ project. Therefore, we are gratitude to Farm Africa for the financial assistances.

\section{REFERENCES}

Azene Bekele (2007). Useful Trees and Shrubs for Ethiopia, Identification, Propagation and Management for 17 Agroclimatic zones. Technical manual, Pp. 550, (Tengnas, B., Ensermu Kelbessa, Sebsebe Demissew and Maundu, P. eds). World Agroforestry Center, English Press, Nairobi, Kenya.

Bhishma, P. S., Shiva, S. P., Ajay, P., Eak, B. R., Sanjeeb, B., Tibendra, R. B., Shambhu, C., and Ri- jan, T. (2010). Forest Carbon Stock Measurement: Guidelines for measuring carbon stocks in community-managed forests. Funded by Norwegian Agency for Development Cooperation (NORAD). Asia Network for Sustainable Agriculture and Bioresources (ANSAB) publishing, Kathmandu, Nepal, Pp.17-43.

Brown, S. (1997). Estimating Biomass and Biomass Change of Tropical Forests: A primer. UN FAO Forestry paper, Rome 134: 20-55.

Brown, S. and Lugo A. E. (1992). Above-ground biomass estimates for tropical moist forests of the Brazilian Amazon. Interciencia 17: 8-18.

Burrows, C.J. (1990). Processes of Vegetation Change. Unwin Hyman Ltd, London.

Cairns, M.A., Olmsted, I., Granados, J. and Argaez, J. (2003). Composition and aboveground tree biomass of a dry semi-evergreen forest on Mexico’s Yucatan Peninsula. Forest Ecol. Manage. 186: 125-132.

Dagnachew Tefera, (2016). Carbon Stock of Meskele Gedam Forest and its Contribution to Climate Change Mitigation, Semen Shewa, Ethiopia. MSc Thesis (unpublished), Addis Ababa University

EFAP (Ethiopian Forestry Action Program) (1994). Ethiopian Forestry Action Program, Vol. 2. The Challenge for Development. Ministry of Natural Resources Development and Environmental Protection, Addis Ababa.

FAO (2006). Global forest resource assessment 2005: Progress towards Sustainable forest management. FAO forestry Paper 147.Rome: FAO.

Gibbs HK, S Brown, JO Niles and JA Foley (2007) Monitoring and estimating forest carbon stocks: Making REDD a reality. Environmental Resource Letters 2: 1-13. 
Houghton, R.A., Lawrence, K.T., Hackler, J.L. and Brown, S. (2001). The spatial distribution of forest biomass in the Brazilian Amazon: a comparison of estimates. Global Change Biology 7: 731-746.

IPCC (2007). Climate change 2007: the physical science basis Lemma, B., Kleja, D., B., Olsson, M., Nilsson, I. (2007).Factors controlling soil organic carbon sequestrationunder exotic tree plantations: A case study using the CO2 Fix model in southwestern Ethiopia. Forest Ecol.Manage. 252(1-3): 124-131.

IPCC. 2003. Good Practice Guidance for Land Use, Land Use Change and Forestry, (Penman, J., Gytarsky, M., Hiraishi, T., Krug, T., Kruger, D., Pipatti, R., Buendia, L., Miwa, K., Ngara, T., Tanabe, K. and Wagner, F. eds). Intergovernmental Panel on Climate Change, Hayama, Japan.

Kent, M. and Coker, P. 1992. Vegetation Description and Analysis. A practical approach. Bolhaven Printing Press, London.

Kidanemariam Kassahun (2014). Forest Carbon Stock in Woody Plants of Ades Forest and its Variation along Environmental Factors: Implication for Climate Change Mitigation, at Western Hararghe, Ethiopia. M.Sc. Thesis (Unpublished). Addis Ababa University, Addis Ababa.

Kirschbaum, M.U. (1996). The carbon sequestration potential of tree plantations in Australia. In: (eds.), Environmental Management: The Role of Eucalypts and Other Fast Growing Species, Eldridge, K.G., Crowe, M.P., Old, K.M. Forestry and Forest Products, 20:77-89.

Perschel, R. T., Alexander, M. E. and Marcia J. S. 2007. Climate Change, Carbon, and the Forests of the Northeast. Forest Guild. Funded by Orchard, Davis Conservation, French, Merck and Surdna Foundation, Santa Fe, pp. $1-10$.

Stern N. (2007). The Economics of Climate Change: the Stern Review. Cambridge: Cambridge University Press. Yitebitu Moges, Zewdu Eshetu and Sisay Nune. 2010. Manual for assessment and monitoring of carbon in forest and other land uses in Ethiopia (Draft). Addis Ababa, Ethiopia.

\section{APPENDICES}

Appendix 1: Estimation of above ground biomass as a function of DBH using regression equations collected from different journal

\begin{tabular}{|c|c|c|c|c|}
\hline Author & Equation & $\begin{array}{l}\text { Applica } \\
\text { bility }\end{array}$ & Life zone & $\begin{array}{l}\mathrm{DBH} \\
\text { range }\end{array}$ \\
\hline FAO (1997) & $\mathrm{Y}=\exp \{1.996+2.32 \times \ln (\mathrm{DBH})\}$ & General & $\begin{array}{l}\text { Dry transition to } \\
\text { moist (rainfall }>900 \mathrm{~mm} \text { ) }\end{array}$ & 5 to $40 \mathrm{~cm}$ \\
\hline FAO (2004) & $\mathrm{Y}=10^{\wedge}(-0.535+\log 10(\pi \times \mathrm{r} 2))$ & General & Dry (rainfall < $900 \mathrm{~mm}$ ) & $<30 \mathrm{~cm}$ \\
\hline FAO (2004) & $\begin{array}{l}Y=\exp \{-2.134+2.530 \\
x \ln (\mathrm{DBH})\}\end{array}$ & General & $\begin{array}{l}\text { Moist (rainfall } 1500 \text { to } \\
4000 \mathrm{~mm} \text { ) }\end{array}$ & \\
\hline $\begin{array}{l}\text { Winrock (from } \\
\text { Brown et al., 1989) }\end{array}$ & $\begin{array}{l}Y=34.4703-8.0671 \mathrm{DBH}+ \\
0.6589 \mathrm{DBH} 2\end{array}$ & General & Dry (rainfall < $1500 \mathrm{~mm}$ ) & $\begin{array}{l}\geq 5 \mathrm{~cm} \\
* *\end{array}$ \\
\hline $\begin{array}{l}\text { Winrock (from } \\
\text { Brown et al., } \\
\text { 1989) }\end{array}$ & $\begin{array}{l}Y=\exp \{-3.1141+0.9719 x \\
\ln [(\mathrm{DBH} 2) \mathrm{H}]\}\end{array}$ & General & $\begin{array}{l}\text { Moist (rainfall } 1500 \text { to } \\
4000 \mathrm{~mm} \text { ) }\end{array}$ & $>5 \mathrm{~cm}$ \\
\hline $\begin{array}{l}\text { Winrock (from } \\
\text { Brown et al., 1989) }\end{array}$ & $\begin{array}{l}\mathrm{Y}=\exp \{-2.4090+0.9522 x \\
\ln [(\mathrm{DBH}) H S]\}\end{array}$ & General & $\begin{array}{l}\text { Moist (rainfall } 1500 \text { to } \\
4000 \mathrm{~mm} \text { ) }\end{array}$ & $>5 \mathrm{~cm}$ \\
\hline Luckman (1997) & $\begin{array}{l}\mathrm{Y}=(0.0899((\mathrm{DBH} 2) 0.9522) \times \\
(\mathrm{H} 0.9522) \times(\mathrm{S} 0.9522))\end{array}$ & General & Not specified & $\begin{array}{l}\text { Not } \\
\text { specified }\end{array}$ \\
\hline Murali KS (2005) & $\mathrm{Y}=-12.05+0.876(\mathrm{BA})$ & General & Rainfall $1378 \pm 116.86 \mathrm{~mm}$ & $\begin{array}{l}\text { Not } \\
\text { specified }\end{array}$ \\
\hline $\begin{array}{l}\text { Brown (1997) } \\
\text { Nelson et al., } \\
(1999)\end{array}$ & $\begin{array}{l}\mathrm{Y}=0.139 * \mathrm{DBH} 2.32 \\
\ln (\mathrm{DW} 1)=-2.5202+2.14 \ln (\mathrm{D}) \\
+0.4644 * \ln (\mathrm{H})\end{array}$ & $\begin{array}{l}\text { General } \\
\text { General }\end{array}$ & $\begin{array}{l}\text { Dry }<1500 \mathrm{~mm} \\
\text { Around } 2000 \mathrm{~mm}\end{array}$ & $\begin{array}{l}5 \text { to } 40 \mathrm{~cm} \\
<25 \mathrm{~cm}\end{array}$ \\
\hline
\end{tabular}


Appendix 2: Above ground carbon stock of the Kubayo Forest

\begin{tabular}{|c|c|c|c|c|c|}
\hline Plot & AGB (Kg/plot) & $\operatorname{AGB}\left(\mathrm{Kg} / \mathrm{m}^{2}\right)$ & AGB (ton/ha) & $\mathrm{AGC}$ (ton/ha & $\begin{array}{l}\mathrm{AGCO}_{2} \\
\text { (ton/ha) }\end{array}$ \\
\hline P1 & 5335.01 & 26.68 & 266.75 & 133.38 & 489.49 \\
\hline $\mathrm{P} 2$ & 5843.46 & 29.22 & 292.17 & 146.09 & 536.14 \\
\hline P3 & 5707.12 & 28.54 & 285.36 & 142.68 & 523.63 \\
\hline P4 & 6656.87 & 33.28 & 332.84 & 166.42 & 610.77 \\
\hline P5 & 5251.98 & 26.26 & 262.6 & 131.3 & 481.87 \\
\hline P6 & 5579.50 & 27.9 & 278.97 & 139.49 & 511.92 \\
\hline P7 & 5413.38 & 27.07 & 270.67 & 135.33 & 496.68 \\
\hline P8 & 6772.48 & 33.86 & 338.62 & 169.31 & 621.38 \\
\hline P9 & 6740.33 & 33.7 & 337.02 & 168.51 & 618.42 \\
\hline $\mathrm{P} 10$ & 6568.54 & 32.84 & 328.43 & 164.21 & 602.66 \\
\hline P11 & 6553.89 & 32.77 & 327.69 & 163.85 & 601.32 \\
\hline $\mathrm{P} 12$ & 4580.46 & 22.9 & 229.02 & 114.51 & 420.26 \\
\hline P13 & 5157.83 & 25.79 & 257.89 & 128.95 & 473.23 \\
\hline P14 & 5034.21 & 25.17 & 251.71 & 125.86 & 461.89 \\
\hline P15 & 3241.36 & 16.21 & 162.07 & 81.03 & 297.4 \\
\hline P16 & 5421.24 & 27.11 & 271.06 & 135.53 & 497.4 \\
\hline P17 & 4830.22 & 24.15 & 241.51 & 120.76 & 443.17 \\
\hline P18 & 4746.75 & 23.73 & 237.34 & 118.67 & 435.51 \\
\hline P19 & 6134.39 & 30.67 & 306.72 & 153.36 & 562.83 \\
\hline P20 & 5826.14 & 29.13 & 291.31 & 145.65 & 534.55 \\
\hline P21 & 5898.79 & 29.49 & 294.94 & 147.47 & 541.21 \\
\hline P22 & 6341.33 & 31.71 & 317.07 & 158.53 & 581.82 \\
\hline P23 & 6895.34 & 34.48 & 344.77 & 172.38 & 632.65 \\
\hline P24 & 4121.65 & 20.61 & 206.08 & 103.04 & 378.16 \\
\hline P25 & 4530.84 & 22.65 & 226.54 & 113.27 & 415.7 \\
\hline P26 & 5785.50 & 28.93 & 289.27 & 144.64 & 530.82 \\
\hline P27 & 5694.64 & 28.47 & 284.73 & 142.37 & 522.48 \\
\hline P28 & 6207.09 & 31.04 & 310.35 & 155.18 & 569.50 \\
\hline P29 & 4588.12 & 22.94 & 229.41 & 114.7 & 420.96 \\
\hline P30 & 5732.00 & 28.66 & 286.6 & 143.3 & 525.91 \\
\hline P31 & 6901.18 & 34.51 & 345.06 & 172.53 & 633.18 \\
\hline P32 & 6383.13 & 31.92 & 319.16 & 159.58 & 585.65 \\
\hline P33 & 5704.71 & 28.52 & 285.24 & 142.62 & 523.41 \\
\hline P34 & 6387.43 & 31.94 & 319.37 & 159.69 & 586.05 \\
\hline P35 & 6668.23 & 33.34 & 333.41 & 166.71 & 611.81 \\
\hline P36 & 5116.76 & 25.58 & 255.84 & 127.92 & 469.46 \\
\hline P37 & 4141.02 & 20.71 & 207.05 & 103.53 & 379.94 \\
\hline P38 & 5701.86 & 28.51 & 285.09 & 142.55 & 523.15 \\
\hline P39 & 4139.97 & 20.7 & 207 & 103.5 & 379.84 \\
\hline $\mathrm{P} 40$ & 6652.93 & 33.26 & 332.65 & 166.32 & 610.41 \\
\hline P41 & 5762.05 & 28.81 & 288.1 & 144.05 & 528.67 \\
\hline P42 & 6226.26 & 31.13 & 311.31 & 155.66 & 571.26 \\
\hline P43 & 6201.12 & 31.01 & 310.06 & 155.03 & 568.95 \\
\hline P44 & 5912.35 & 29.56 & 295.62 & 147.81 & 542.46 \\
\hline P45 & 5956.32 & 29.78 & 297.82 & 148.91 & 546.49 \\
\hline P46 & 4925.23 & 24.63 & 246.26 & 123.13 & 451.89 \\
\hline P47 & 5947.56 & 29.74 & 297.38 & 148.69 & 545.69 \\
\hline P48 & 6136.12 & 30.68 & 306.81 & 153.40 & 562.99 \\
\hline P49 & 6489.45 & 32.45 & 324.47 & 162.24 & 595.41 \\
\hline P50 & 6136.23 & 30.68 & 306.81 & 153.41 & 563.00 \\
\hline P51 & 6012.35 & 30.06 & 300.62 & 150.31 & 551.63 \\
\hline P52 & 4896.36 & 24.48 & 244.82 & 122.41 & 449.24 \\
\hline P53 & 5897.35 & 29.49 & 294.87 & 147.43 & 541.08 \\
\hline P54 & 5889.48 & 29.45 & 294.47 & 147.24 & 540.36 \\
\hline P55 & 5968.78 & 29.84 & 298.44 & 149.22 & 547.64 \\
\hline P56 & 5989.25 & 29.95 & 299.46 & 149.73 & 549.51 \\
\hline
\end{tabular}




\begin{tabular}{lrrrrr}
\hline Plot & AGB $(\mathrm{Kg} /$ plot $)$ & $\mathrm{AGB}\left(\mathrm{Kg} / \mathrm{m}^{2}\right)$ & $\mathrm{AGB}($ ton $/ \mathrm{ha})$ & $\mathrm{AGC}($ ton $/$ ha & $\begin{array}{l}\mathrm{AGCO}_{2} \\
\text { (ton/ha) }\end{array}$ \\
\hline P57 & & & 319.91 & 159.96 & 587.04 \\
P58 & 6398.28 & 31.99 & 249.49 & 124.75 & 457.82 \\
P59 & 4989.89 & 24.95 & 249.92 & 124.96 & 458.60 \\
P60 & 4998.36 & 24.99 & 299.49 & 149.74 & 549.56 \\
P61 & 5989.79 & 29.95 & 165.85 & 82.92 & 304.33 \\
P62 & 3316.98 & 16.58 & 299.48 & 149.74 & 549.55 \\
P63 & 5989.61 & 29.95 & 222.36 & 111.18 & 408.04 \\
Average & 4447.28 & 22.24 & 282.11 & 141.06 & 517.68 \\
Max & 5642.29 & 28.21 & 345.06 & 172.53 & 633.18 \\
Min & 6901.18 & 34.51 & 162.07 & 81.03 & 297.40 \\
STDEVA & 3241.36 & 16.21 & 44.09 & 22.04 & 80.90 \\
Low & 881.77 & 4.41 & 282.00 & 141.00 & 517.47 \\
Middle & 5640.03 & 28.20 & 290.58 & 145.29 & 533.21 \\
High & 5811.60 & 29.06 & 273.76 & 136.88 & 502.35 \\
0-20 & 5475.23 & 27.38 & 282.00 & 141.00 & 517.47 \\
21-40 & 5640.03 & 28.20 & 285.47 & 142.74 & 523.84 \\
>40 & 5709.47 & 28.55 & 276.15 & 138.08 & 506.74 \\
\hline
\end{tabular}

